\title{
Den grønlandske forbindelse
}

Marc Jacobsen

Danmarks tilstedeværelse i Arktis er helt $\mathrm{og}$ aldeles afhængig af, at rigsfællesskabet består. Uden Grønland ville Danmark miste muligheden for at sidde til højbords med USA, Rusland og Canada. En mulighed som, Danmarks størrelse taget i betragtning, er helt unik og af uvurderlig betydning for Danmarks plads i det globale hierarki. Det er derfor alfa og omega, at Danmark fortsat plejer forholdet til Grønland med stor omhu, og at eventuelle uenigheder mellem Nuuk og København bliver taget seriøst og behandlet med stor, gensidig respekt.

Udenrigsministeriet er fuldt bevidst om vigtigheden af rigsfællesskabets fortsatte beståen, og det var derfor ingen overraskelse, at en af Kristian Jensens første rejser som nyudnævnt udenrigsminister gik til Grønland. I forbindelse med sit besøg i august 2015 udtalte Jensen: "Jeg er glad for, at jeg så hurtigt kunne tage til Grønland. Samarbejdet med Grønland, rigsfællesskabet og hele spørgsmålet om Arktis er strategisk vigtigt for mig og regeringen. Derfor er jeg glad for at lære den grønlandske rege- ring godt at kende og udbygge det tætte samarbejde med Grønland. Det samarbejde gør os større i verden". Udtalelsen understreger, at Arktis er en af Danmarks udenrigspolitiske hovedprioriteter, og at vejen dertil går via Grønland.

To uger efter besøget rejste Kristian Jensen med sin grønlandske kollega, Naalakkersuisoq for Udenrigsanliggender Vittus Qujaukitsoq, til Anchorage, Alaska, hvor John Kerry var vært for GLACIER-konferencen. Til lyden af blitzende kameraer og øredøvende klapsalver kiggede også Barack Obama forbi konferencen. Alle ville udveksle ord og håndtryk med Obama, der med sit besøg blev den første regerende amerikanske præsident i Alaska - og i Arktis i øvrigt.

Jensens og Qujaukitsoqs taletid var derfor meget begrænset, men da muligheden endelig bød sig, så Jensen sit snit til at invitere Obama til Grønland for at opleve klimaforandringernes synlige konsekvenser på nærmeste hold. Så vidt vides har Obama endnu ikke takket ja til invitationen, men lykkes det, vil det være et udenrigspolitisk scoop for Rigsfællesskabet. Tidligere har blandt andre Hillary Clinton, Sergei Lavrov og Ban Ki-Moon været på

Marc Jacobsen er ph.d.-studerende ved Statskundskab, Københavns Universitet. Artiklen vandt en delt andenpris i Det Udenrigspolitiske Selskabs og Udenrigsministeriets artikelkonkurrence. 
I takt med at forholdet mellem Øst og Vest langsomt tøede op, vandt mellemstatslige samarbejder i højere grad frem i Arktis. Mikhail Gorbachevs berømte tale i Murmansk i 1987 udstak kursen for denne udvikling, da han blandt andet sagde: "Let the North of the globe, the Arctic, become a zone of peace."

lignende besøg i Grønland. Besøg, der ikke alene har budt på gyldne kodakmoments foran isbjergene i Diskobugten og på toppen af indlandsisen, men også på uforlignelige muligheder for at styrke de bilaterale relationer med nogle af verdens mest indflydelsesrige personer. Relationer, der har stor betydning for, at Danmark kan pleje sine strategiske interesser i Arktis og i verden i øvrigt.

\section{'Grønlandskortet' og de geopolitiske interesser}

Under den kolde krig var interessen for Arktis præget af den bipolare verdensorden, hvor atomdrevne ubåde og betyde lige militære installationer dominerede den arktiske virkelighed. I denne virkelighed havde Grønland en strategisk vigtig placering mellem Nordamerika og Sovjetunionen. Med tilladelse fra Danmark oprettede USA derfor Thule Air Base og, ikke langt derfra, Camp Century, beliggende inde på indlandsisen. Planen var her at udvikle et tophemmeligt, mobilt missilforsvar kendt under navnet 'Project Iceworm', men på grund af isens ustabilitet blev projektet droppet. Til gengæld for denne forsvarsaftale har Danmark i mange år fået rabat på sit NATOmedlemskab, så man har sluppet med betydeligt mindre end NATO-målsætningen på to pct. af BNP. Denne rabat er almindeligt kendt som, at Danmark har spillet 'Grønlandskortet'.

I takt med at forholdet mellem Øst og Vest langsomt tøede op, vandt mellem- statslige samarbejder i højere grad frem i Arktis. Mikhail Gorbachevs berømte tale i Murmansk i 1987 udstak kursen for denne udvikling, da han blandt andet sagde: "Let the North of the globe, the Arctic, become a zone of peace. Let the North Pole be a pole of peace" og "The Soviet Union proposes drawing up jointly an integrated comprehensive plan for protecting the natural environment of the North".

Gorbachevs tale satte gang i en proces, der i 1991 resulterede i Arctic Environmental Protection Strategy, der var forløberen til Arktisk Råd, som blev etableret i 1996. Katalysatoren bag udviklingen var - og er - de globale klimaforandringer, der er særligt mærkbare i det høje nord, hvor gennemsnitstemperaturen er steget dobbelt så meget som i resten af verden i løbet af de seneste 50 år.

I 1990'erne var fokus næsten udelukkende på de negative konsekvenser af de højere temperaturer i Arktis, hvor truslen mod de lokale dyr og de oprindelige befolkningers levegrundlag var de primære bekymringer. I dag er perspektivet mere nuanceret, med fokus på både risici og nye muligheder. Det allestedsnærværende, centrale kodeord, der relaterer til både risici og mulighederne i Arktis, er nu 'bæredygtig udvikling'.

\section{Nye muligheder}

Tre begivenheder i midten af 00'erne skabte for alvor stor global opmærksomhed om de nye muligheder i Arktis: 
1) Den 2. august 2007 plantede Rusland et titaniumflag på den geografiske Nordpol, 4.261 meter under havets overflade i Det Arktiske Ocean, et af klodens sidste terra nullius (ingenmandsland). Det fik hurtigt repræsentanter fra Det Hvide Hus og 24 Sussex Drive op af stolene med udtalelser om, at flagplantning hørte til i det 15. Århundrede, og at det absolut ingen juridisk status havde.

2) Året efter offentliggjorde U.S. Geological Survey målinger, der viste, at den arktiske region indeholder henholdsvis ca. 13 og 30 pct. af verdens uopdagede olie- og gasressourcer.

3) Det skete samtidig med, at den globale oliepris nåede de magiske 100 dollar per tønde i starten af 2008 og toppede med 147 dollar i juli måned samme år.

Sammen med interessen for nye potentielle sejlruter nord om Rusland og Nordamerika resulterede disse tre begivenheder i fornyet interesse for Arktis i alverdens udenrigskontorer og nyhedsredaktioner. Resultatet var i første omgang en udbredt Klondike-stemning og en vis tilfrysning af den gamle Øst-Vest koldfront.

Daværende udenrigsminister Per Stig Møller tog udviklingen dybt alvorligt. Som beskrevet i Martin Breums bog Når Isen Forsvinder vågnede han op en morgen "badet i sved og hovedet fuld af russiske ubåde". Det stod klart, at der måtte gøres noget. Møller tog derfor initiativ til at samle repræsentanter fra 'de arktiske fem' - Canada, USA, Norge, Rusland og Kongeriget Danmark - med grænser op til Det Arktiske Ocean. Sammen skulle de finde frem til en fælles, fredelig løsning på den fremtidige fordeling af det enorme område.

Den 28. maj 2008 resulterede mødet i den historiske Ilulissat-erklæring, der slår fast, at videnskabelig, geologisk data og international lov skal danne grundlaget for fordelingen. Erklæringen var samtidig et signal til omverdenen om, at fordelingen er et internt anliggende for de fem, og at hverken fremmede stater eller kreative, internationale traktater - som man kender det fra Antarktis - skal forhindre dem, der betragter sig som områdets retmæssige ejere i at gøre, hvad de vil. Erklæringen var en stor fjer i hatten på Per Stig Møller og det danske udenrigsministerium, der for alvor trådte ind på scenen som en af hovedaktørerne i den arktiske dynamik.

\section{Kontinentalsokkelprojektet}

Allerede fem år tidligere var de spæde skridt til rigsfællesskabets kontinentalsokkelprojekt taget. Det skete, da Folketinget besluttede at afsætte penge til det storstilede projekt og at ratificere FN's Havretskommission (UNCLOS). Dermed lød startskuddet til præcis ti års geologisk dataindsamling.

Tre ekspeditioner - LOMROG I, II og III - har ved hjælp af den nyeste teknologi og med assistance fra svenske og russiske isbrydere samlet så store mængder data, at man mener at have belæg for en udvidelse af Kongeriget Danmark med hele $895.000 \mathrm{~km} 2$ havbund. Det svarer til 19 gange Danmarks nuværende areal og næsten halvdelen af Grønlands.

Kravet, som blev indleveret til FN's Kommission for Kontinentalsoklens Grænser (CLCS) den 15. december 2014, inkluderer Nordpolen og overlapper med 
Ruslands og sandsynligvis også Canadas krav. På trods af det, og takket være Ilulissat-erklæringen, forløber processen indtil videre helt som planlagt. Forude venter mange års uvished, før CLCS måske finder en afgørelse. En afgørelse, der meget vel kan vise sig at give flere ret til det samme område.

Hvis det er tilfældet, vil der blive brug for alle rigsfællesskabets juridiske og diplomatiske kapaciteter, så man ikke bliver trynet af to så store magter som Rusland og Canada. Med det fælles mål for øje er Grønland dybt afhængig af et fortsat nært samarbejde med Danmark. Særligt interessant, fordi det tildelte areal i sidste ende tilfalder Grønland.

\section{Danmarks Arktis-perspektiv}

Den fornyede interesse for Arktis i midten af 00'erne afspejledes i de arktiske staters gensidige positionering og udenrigspolitiske opprioritering af det arktiske område. Strategier for Arktis blev det nye sort. Først kom Norge med deres 'Nordområdestrategi' (2006), dernæst fulgte Rusland (2008), Canada (2009), Finland (2010), Island (marts 2011) og Sverige (maj 2011), før 'Kongeriget Danmarks Strategi for Arktis 2011-2020' så dagens lys i august 2011. Kun USA var langsommere med deres strategi, der først udkom i 2013.

Som noget nyt anerkender rigsfællesskabets arktiske strategi, at fremtidig konflikt er en mulig konsekvens af den øgede aktivitet i det høje nord. Den understreger dog samtidig, at mellemstatsligt samarbejde er den bedste vej frem for alle parter. Bedre beredskab og øget overvågning er to centrale prioriteter, som skal sikre suverænitetshåndhævelse og større sikkerhed til søs.
Strategien anno 2011 var et af de første tegn på et bredere dansk Arktis-perspektiv, der inden da havde været mere snævert koncentreret om Grønland. I perioden 1941-1992 var Arktis i Udenrigsministeriets optik lig med relationen til USA via Thulebasen. Selve forholdet til Grønland var en sag for Statsministeriet og Grønlandsministeriet. I årene efter fulgte en periode, hvor Arktis gik lidt i den udenrigspolitiske glemmebog, for igen at blive støvet af og taget frem i 00'erne.

Dog var det genfundne perspektiv stadig hovedsageligt rettet mod Grønland, godt eksemplificeret ved dokumentet 'Arktis i en brydningstid - Forslag til strategi for aktiviteter i det arktiske område', der blev offentliggjort som optakt til topmødet i Ilulissat i 2008. Dokumentet handler i overvejende grad om oprindelige folks rettigheder, hjemmestyreordningen, forholdet til USA, Grønlands naturressourcer og dets handelsforbindelser. Danmarks rolle nedtones, mens Færøerne stort set udelades. Det skyldtes sandsynligvis den dengang igangværende proces frem mod indførelsen af Grønlands Selvstyre i 2009.

Samtidig var Danmarks udenrigspolitiske topprioritet dengang krigene i Irak og Afghanistan, hvor man dannede fælles front med amerikanerne i kampen mod terrorister og såkaldte slyngelstater. Problemerne i Mellemøsten er ikke blevet færre siden da, men Danmarks militærstrategiske overvejelser er nu i højere grad også orienteret mod Arktis. Således forventes det, at de næste større militære investeringer vil være tilpasset forholdene og udfordringerne i det kolde nord frem for det varme syd. 


\section{Et bredere perspektiv}

Det bredere perspektiv på hele den arktiske region afspejles i etableringen af 'Kontoret for Arktis og Nordamerika' på Asiatisk Plads 2 og i oprettelsen af posten som arktisk ambassadør i 2012. Den nuværende ambassadør, og den anden i rækken, Erik Vilstrup Lorenzen, har blandt andet en fortid som ambassadør i Canada.

Det er helt i tråd med udviklingen $\mathrm{i}$ Danmarks bredere Arktis-fokus, hvor gode relationer til de andre magtfulde arktiske stater er yderst vigtige, når der skal findes svar på store spørgsmål om grænsedragninger, suverænitetshåndhævelse, klimaforandringer og sikkerhed til søs.

Opprioriteringen af det høje nord afspejles også i det voksende antal ansatte i Arktis-kontoret over årene. Samtidig med denne udvikling har antallet af ansatte med særligt kendskab til grønlandske forhold modsat været faldende. Hvad udadtil er vundet, er - til en vis grad tabt indadtil. For den store viden om grønlandske forhold, som tidligere har kendetegnet Udenrigsministeriets fokus på Arktis, er mindsket i takt med opprioriteringen af et bredere perspektiv. Det kan vise sig at være en ulempe i forhold til at pleje de tætte bånd til Grønland, der ellers er Danmarks eneste forbindelse til de bonede gulve i Arktis.

Sagen om Thulebasens servicekontrakt er et eksempel på en sag, som muligvis kunne være undgået, hvis Udenrigsministeriet havde haft flere ansatte med indgående kendskab til grønlandske forhold. Kort fortalt skete der det, at det danskgrønlandsk ejede Greenland Contractors i efteråret 2014 tabte servicekontrakten til Exelis Services, der er ejet af den ame- rikansk gigant, Vectrus. Med tabet stod Grønlands Landskasse til at miste ca. ti pct. af landets samlede skatteindtægter, da Exelis Services sandsynligvis ville ansætte billigere amerikansk arbejdskraft, som ikke ville være forpligtiget til at betale skat i Grønland, jævnfør forsvarsaftalen fra 1951.

Sagen skabte derfor stor røre i det grøn landske samfund. I maj 2015 blev kontrakten imidlertid underkendt af US Court of Federal Claims, fordi Exelis Services reelt er et skuffeselskab. I stedet blev aftalen med Greenland Contractors forlænget til september 2016, så der er tid nok til at finde en løsning, der ikke har så store negative konsekvenser for den i forvejen hårdt trængte grønlandske økonomi.

Hvis det gode forhold til Grønland skal bevares og eventuelt forbedres, er det helt centralt at undgå lignende sager. I det lys kunne det være en fordel, hvis Udenrigsministeriet udvidede 'Kontoret for Arktis og Nordamerika' med flere personer med indgående kendskab til grønlandske forhold.

Sagen vidner imidlertid også om, at der i Grønlands Udenrigsdirektorat er en mangel på folk med stor viden om sikkerhedspolitiske forhold. Derfor kunne det være i alles interesse, hvis vidensudvekslingen mellem Danmarks Udenrigsministerium og Grønlands Udenrigsdirektorat blev forbedret og eventuelt suppleret med en aftale om udveksling af medarbejdere i halvårlige perioder. Sådanne udvekslinger kunne styrke den gensidige tillid, nuancere medarbejdernes viden og bidrage til at undgå sager eller misforståelser, som kunne risikere at skade forholdet mellem Danmark og Grønland. 


\section{Grønlands fornemmelse for selvstændighed}

Juridisk set er vejen banet for, at Grønland kan kappe båndene til Danmark, når den grønlandske befolkning ønsker det. Det er slået fast i Grønlands Selvstyrelov, $\$ 21$.

De økonomiske realiteter gør dog, at en sådan beslutning i øjeblikket har lange udsigter, da bloktilskuddet på 3,64 mia. danske kroner årligt udgør ca. 60 pct. af Grønlands samlede offentlige budget (2014).

Fuld selvstændighed på nuværende tidspunkt ville derfor resultere i uanstændige forringelser af den generelle grønlandske levestandard, med mindre man gør store råstoffund samtidig med, at de nuværende globale råstofpriser stiger. I skrivende stund begrænser Grønlands råstofaktiviteter sig til en mindre rubinmine, der er under opførelse i Qeqertarsuatsiaat. Det batter ikke så meget i det store billede.

Ifølge rapporten 'Til Gavn for Grønland' vil det kræve 24 storskalaminer på samme tid, hvis bloktilskuddet skal udlignes. Finder man olie er det en helt anden snak, men gentagne efterforskninger siden 1970'erne har endnu ikke resulteret i nogen form for olieproduktion, så det lader ikke umiddelbart til at være den korteste vej til øget økonomisk selvstændighed.

Samtlige partier i Inatsisartut (Grønlands parlament) er enige om, at selvstændighed er det ultimative mål. Men hvad betyder selvstændighed? Udelukker det eksempelvis en fortsat nær relation til Danmark? Svarene på disse spørgsmål opløser den entydige enighed mellem partierne.

De borgerlige partier, Atassut og Demokraatit, er historisk set grundlagt med for- målet om at bibeholde en nær relation til Danmark, og den dag i dag er de stadig varme fortalere for rigsfællesskabets beståen.

Inuit Ataqatigiit og Siumut - der ofte bliver sammenlignet med Socialistisk Folkeparti og Socialdemokratiet - blev i sin tid dannet i opposition til Danmark og danskernes ageren i Grønland. I dag er de begge stadig store fortalere for at begrænse Danmarks medbestemmelse, men tonen over for den tidligere kolonimagt er blevet mere forsonelig. Som udspringer af Siumut placerer Partii Naleraq sig nogenlunde samme sted, imens Partii Inuit, der røg ud af Inatsisartut ved sidste valg, lægger skarp afstand til alt, hvad der er dansk.

Uanset hvad partierne lægger i begrebet 'selvstændighed', så må det nødvendigvis indebære en udvikling, hvor Grønland opnår endnu større selvbestemmelse og dermed en større eller mindre forandring af rigsfællesskabets nuværende konstellation. Med Ulrik Pram Gads ord kan man sige, at modsat EU's mission om 'an ever closer union', er der i rigsfællesskabets tilfælde i stedet tale om en udvikling frem mod 'an ever looser union'.

Under Aleqa Hammonds kommando (5. april 2013 - 30. september 2014) nåede selvstændighedsretorikken hidtil usete højder. Det skete især, når det ulige repræsentationsforhold blev tydeligt, som i eksempelvis Arktisk Råd, hvor Danmark taler på vegne af rigsfællesskabets samlede delegation.

I maj 2013 blev det for meget for Aleqa Hammond, der under stor mediebevågenhed boykottede Arktisk Råds møde i Kiruna, Sverige. Hammond glimrede ved sit fravær og slog tonen an for sin storm- 
Hvis Danmark fortsat skal have en stemme i Arktis, er det vigtigt, at Grønland føler sig som en mere ligeværdig partner, end hvad tilfældet er i dag. Statsminister Lars Løkke Rasmussen gjorde det klart på rigsmødet i december 2015, at rigsfællesskabets beståen er fuldstændig afhængig af, at alle tager aktivt del i det: “Det er ligesom et ægteskab. Det kan man ikke holde fast i, hvis den ene part gerne vil skilles".

fulde regeringsperiode. Den konkrete episode mødte stor kritik i Inatsisartut, men ikke desto mindre tegnede den et billede af en udbredt utilfredshed med Grønlands begrænsede stemme i egne internationale relationer.

Mindre demonstrative, men dog ligeså klare holdninger er udtrykt fra hele paletten af grønlandske politikere i sagerne om hvalfangstkvoter og EU's importforbud af sælprodukter. I de sager er Grønland underlagt et lignende repræsentationsforhold i henholdsvis Den nternationale Hvalfangstkommission (IWC) og Verdenshandelsorganisationen (WTO).

Sammen med uenigheden om hvorvidt uran og sjældne jordarter er et sikkerhedspolitisk spørgsmål og dermed Danmarks ansvar, har disse sager forårsaget en udbredt grønlandsk utilfredshed med rigsfællesskabets ulige repræsentationsforhold.

\section{Hvad bør Danmark gøre?}

Hvis Danmark fortsat skal have en stemme i Arktis, er det vigtigt, at Grønland føler sig som en mere ligeværdig partner, end hvad tilfældet er i dag. Statsminister Lars Løkke Rasmussen gjorde det klart på rigsmødet i december 2015, at rigsfællesskabets beståen er fuldstændig afhængig af, at alle tager aktivt del i det: "Det er ligesom et ægteskab. Det kan man ikke holde fast $\mathrm{i}$, hvis den ene part gerne vil skilles".
Det kan måske virke som en vovet udmelding, men ikke desto mindre er åbenhed og ærlighed vejen frem, hvis tilliden skal forbedres. Og det skal den. Danmark bør ikke lægge skjul på, at bloktilskuddet ikke udelukkende gives for grønlændernes brune øjnes skyld. Klare dagsordener og utvetydige udtalelser er vejen frem i skabelsen af et mere ligeværdigt forhold.

Et andet godt eksempel er forhenværende udenrigsminister Martin Lidegaards befriende klare udmelding i Martin Breums bog Balladen om Grønland. Her udtaler han blandt andet at: "Danmark er større og mere betydningsfuld sammen med Grønland, end vi ville være alene. Vi har en interesse $i$ at fastholde det fællesskab”. Klar tale, der bør være et eksempel til efterfølgelse.

En ting er politik og formelle forbindelser, noget andet er følelser, familiebånd og fælles traditioner. Til syvende og sidst er det de personlige forhold og den fælles kulturarv, der binder rigsfællesskabets dele sammen.

Det er derfor også i strategisk henseende værd at fremhæve de bløde værdier og de mere jordnære relationer. I den sammenhæng kan medierne spille en vigtig rolle ved i højere grad at sætte fokus på rigsfællesskabet, så især folk i Danmark får en bedre forståelse af, hvad der foregår på øerne i Nordatlanten. Både nyheder, dokumentarer og fjernsyn for børn bør oftere fortælle om livet i 
Grønland og Færøerne. Dertil bør folkeskolen også komme mere på banen med feature-uger om rigsfællesskabet og lejrskoler på Færøerne og i Grønland. Det er sådanne oplevelser, der er med til at skabe nysgerrighed, nuancere forståelsen, nedbryde fordomme og danne personlige relationer, der er det lim, som binder rigsfællesskabet sammen.

Fortællinger kan have betydelig indflydelse på folks ageren, og hvis den er effektiv og vel-timet, kan den sågar have politisk indflydelse med vidtrækkende konsekvenser. I Grønland er kongehuset umådeligt populært. Dronning Margrethe og Prins Henrik gengælder glæden og er flittige til at besøge selv de mindste bygder.

Kronprins Frederik har en fortid i Siriuspatruljen, og kronprinsparrets tvillinger har hver især fire navne, hvoraf et er grønlandsk: Minik og Ivalo. Det skyldes formentligt parrets store begejstring for Grønland, men valget af navne kan også have en strategisk betydning med det formål at binde kongerigets dele tættere sammen.

Hvorvidt det har været tanken, er uvist, men historien taler umiddelbart imod. Dronningens fulde navn er Margrethe Alexandrine Pórhildur Ingrid, hvoraf pórhildur er islandsk. Navnene fik hun den 14. maj 1940. Få år efter, i 1944, blev Island en selvstændig republik. Navnene kan dog også blot være ment som en velmenende gestus som gengældelse for den glæde, grønlænderne udviser over for den royale familie. Uanset hvad, er det kun med til at højne kongehusets popularitet i Grønland og det kan alt andet lige ikke belaste rigsfællesskabets sammenhængskraft.

Det danske erhvervsliv og pensionskasser bør også komme mere på banen med investeringer i grønlandske råstofprojekter, som med risikovillig kapital kan udvikle sig til fordel for alle parter. For Grønland vil det være et tiltrængt skub i en mere positiv retning, mens udvidelsen af de professionelle relationer $\mathrm{i}$ både mængde og kvalitet vil styrke relationerne mellem rigsdelene. Det kan både ske i stor skala i form af minedrift, men også i mindre skala, som eksempelvis det nye dansk-grønlandske enzymprojekt, som udvinder koldtvandsenzymer af ikait-søjlerne i Nuukfjorden. Mange bække små. Det vigtigste er, at nogen viser vejen, så der bliver skabt optimisme omkring de økonomiske muligheder i Grønland.

Forskningen har også en central rolle i denne udvikling, og det bør være en hovedprioritet at skabe de bedst mulige forhold for dansk Arktis- og Grønlandsforskning. Forskningen kan lede til konkrete projekter, som det om koldtvandsenzymer, bidrage til den almene forståelse af den fælles historie og give nyttig viden om de politiske vinde i det høje nord til gavn for rigsfællesskabets strategiske interesser i området. Senere i 2016 ser en ny strategi om dansk polarforskning dagens lys, men allerede nu er det slået fast, at der ikke følger en ny pose penge med strategien. Skal det rykke noget, skal der kroner på bordet. Ellers er man lige vidt. Regeringen er nødt til at sætte handling bag ordene og dermed også opprioritere Arktis i økonomisk henseende.

Betydningen af at have adgang til det eksklusive selskab i Arktisk Råd og klubben af de handlekraftige 'arktiske 5 ' må ikke undervurderes for et lille land som Danmark. Tilstedeværelsen har stor betydning for, at Danmark 'punches 
above its weight' i Arktis til gavn for Danmarks rolle på den internationale scene i øvrigt.

Rigsfællesskabets beståen er det, der legitimerer Danmarks tilstedeværelse i Arktis. Derfor bør det være en væsentlig del af Danmarks strategi at forbedre det nuværende forhold til Grønland. Det gøres ved en mere åben og ærlig dialog, øget gensidig vidensudveksling, ved at tilstræbe større lighed rigsdelene imellem, tilskynde og fremme fælles værdier og relationer, og ved også økonomisk at opprioritere det arktiske område.

Hvis tilliden forbedres og ord bakkes op med handling, kan rigsfællesskabet sammen udrette store ting i Arktis. Som den store dansk-grønlandske polarfarer Knud Rasmussens ville have sagt: Fremad! Den der raster, ruster! 